\title{
ANALOGOUS GROUNDS OF DISCRIMINATION UNDER THE CANADIAN CHARTER: TOO MUCH ADO ABOUT NEXT TO NOTHING
}

\section{DALE GIBSON*}

Section 15 of the Canadian Charter of Rights and Freedoms prohibits discrimination based on an openended list of grounds. Ever since the section was proclaimed, courts have been wrestling with the question of which grounds of discrimination not specifically listed in s. 15 are nonetheless prohibited by it. It is now generally accepted that such grounds must be "analogous" to the listed grounds. However, there is no general agreement on what "analogous" means. Professor Gibson describes five distinct ways in which the courts have approached the question of analogousness before concluding that they might do better to avoid the question altogether.
L'article 15 de la Chante canadienne des droits et libertés interdit la discrimination fondée sur une liste ouverte de motifs. Mais depuis sa proclamation, les tribunaux s'interrogent sur les motifs qui peuvent être invoqués, bien que ne figurant pas à l'article 15. On exige généralement qu'ils soient «analogues» aux motifs expressément énumérés mais sans toutefois s'entendre sur le sens du terme. Le professeur Gibson décrit cinq façons distinctes dont les tribunaux abordent le probleme et conclut qu'ils auraient peut-être avantage à l'eviter complètement.

\section{TABLE OF CONTENTS}

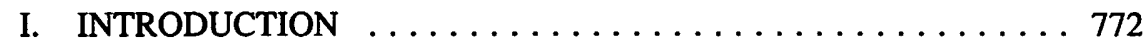

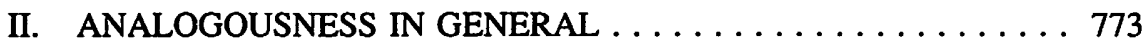

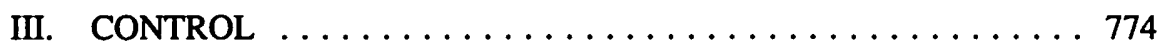

IV. PERSONAL CHARACTERISTICS $\ldots \ldots \ldots \ldots \ldots \ldots \ldots 775$

V. PRIOR GROUP DISADVANTAGE $\ldots \ldots \ldots \ldots \ldots \ldots \ldots \ldots 782$

VI. STABILITY $\ldots \ldots \ldots \ldots \ldots \ldots \ldots \ldots \ldots \ldots \ldots \ldots \ldots$

VII. OTHER CONSTITUTIONAL PROTECTION .......... 788

VIII. CONCLUSION: WHY ARE WE DOING ALL THIS ANYWAY? . 790

\section{INTRODUCTION}

When the Supreme Court of Canada decreed in Andrews v. Law Society of British Columbia' that the forms of discrimination constitutionally prohibited by s. 15(1) of the Canadian Charter of Rights and Freedoms are restricted to the grounds listed therein, and such others as are "analogous" or "kindred" or "similar" to the listed grounds, it created an onerous interpretive task for itself and for subordinate courts. In the short time since Andrews was decided the case law on "analogousness" has been extensive, and it grows by the day.

\section{Professor of Law, University of Manitoba.}

1. [1989] 2 W.W.R. 289 at 312. I expressed the view in The Law of the Charter: Equality Rights (Calgary: Carswell, 1990) at 147-48 that Andrews did not necessarily restrict unlisted forms of discrimination under s. 15(1) of the Charter to those which are analogous to the listed forms. While I still think that was an accurate reading of the decision, it seems futile to persist in the view that the question is still open, given the fact that many courts, including the Supreme Court of Canada itself (Reference Re Workers' Compensation Act, Newfoundland (1989), 56 D.L.R. (4th) 765 at 766, per La Forest J.; Rudolph Wolff \& Co. Ltd. v. R. (1990), 69 D.L.R. (4th) 392 at 398, per Cory J.) seem to have expressed the view that it is not. 
The task undertaken in this paper was to survey the courts' "analogousness" rulings to date, to search for organizing principles, and to offer suggestions for future development of the notion. By the time the research was complete, the writer was convinced that the case law on this question is in a grossly confused state, and that the most useful future development would be to abandon most of what has been decided so far, and begin afresh. Perhaps, indeed, the best solution would be to acknowledge that the question of analogousness is a non-problem.

\section{ANALOGOUSNESS IN GENERAL}

One thing appears to be agreed. It seems likely that the link of similarity required to bring an unlisted form of discrimination within the magic circle of "analogous," "kindred," or "similar" grounds will not necessarily have to be a connection to any particular listed ground. It will probably be sufficient if the unlisted ground exhibits some characteristic common to all the listed categories. This is not to say that similarity to particular listed grounds - sexual orientation to "sex," for example - not be a valid test for analogousness; the point is simply that such direct connections do not appear to be essential. It is noteworthy that little attempt was made in the Andrews case to connect non-citizenship, which the court held to be an "analogous ground," directly to any ground specifically listed in section 15(1), such as "national or ethnic origin." ${ }^{2}$ Instead, the judges seemed to seek characteristics that non-citizenship shares with all the expressly prohibited forms of discrimination. Madame Justice Wilson pointed out that: ${ }^{3}$

Relative to citizens, non-citizens are a group lacking in political power and as such vulnerable to having their interests overlooked and their rights to equal concern and respect violated. They are among "those groups in society to whose needs and wishes elected officials have no apparent interest in attending" ${ }^{4}$ ... Their vulnerability to becoming a disadvantaged group in our society is captured by John Stuart Mill's observation ... that "in the absence of its natural defenders, the interests of the excluded is always in danger of being overlooked ..." I I would conclude therefore that non-citizens fall into an analogous category to those specifically enumerated in s. 15. ... While legislatures must inevitably draw distinctions among the governed, such distinctions should not bring about or reinforce the disadvantage of certain groups and individuals by denying them the rights freely accorded to others.

\section{Mr. Justice La Forest took a similar approach: ${ }^{6}$}

[W]e are concerned in this case with whether or not the legislation amounts to discrimination of a kind similar to those enumerated in s. 15. It was conceded that the impugned legislation does distinguish ...

2. Ibid. La Forest J. did make the connection, however: "Discrimination on the basis of nationality has from early times been an inseparable companion of discrimination on the basis of race and national or ethnic origin, which are listed in s. 15" (at 330-31).

The discussion in this paper of the fact that analogousness is a general quality and not groundspecific is drawn from Gibson, ibid. at 149-50.

3. Supra, note 1 at 323.

4. The quotation is from J.H. Ely, Democracy and Distrust: A Theory of Judicial Review (Cambridge: Harvard University Press, 1980) at 151.

s. Considerations of Representative Government, book III.

6. Ibid. at 330. 
on the basis of a personal characteristic which shares many similarities with those enumerated in s. 15 . The characteristic of citizenship is one typically not within the control of the individual and, in this sense, is immutable. Citizenship is, at least temporarily, a characteristic of personhood not alterable by conscious action and in some cases not alterable except on the basis of unacceptable costs.

Moreover, non-citizens are an example without parallel of a group of persons who are relatively powerless politically, and whose interests are likely to be compromised by legislative decisions.

There the agreement ends. The cases disclose six distinct tests for determining analogousness:

1. Analogousness Alone. "Straight-up" application of the concept, with no supportive tests or guidelines.

2. Lack of Control.

3. Personal Characteristics.

4. Prior Group Disadvantage ("Discrete and insular minorities").

5. Stability ("Immutability").

6. Absence of Other Constitutional Protection.

The first of these approaches - unaided application of the raw notion of analogousness ${ }^{7}$ - is so fact-specific as to preclude academic analysis. The other five will be discussed in the order listed.

Before moving to that discussion, however, it might be useful to indicate in advance two general conclusions that the writer believes the jurisprudence supports:

(a) Most of the decisions purporting to deal with "analogous grounds" have been concerned in reality with other matters.

(b) It is doubtful whether the relatively few rulings that were really about "analogous grounds" have made a significant contribution toward an understanding or effective implementation of the equality guarantees embodied in s. 15(1) of the Charter.

\section{CONTROL}

In a few cases the guiding factor has been held to be the ability of the persons affected to control the characteristic upon which differential treatment is based. In $R$. v. Baig ${ }^{8}$ the legislation prohibiting the practice of psychology by persons not registered as members

7. Eg.: Reference Re Workers' Compensation Act, Newfoundland, supra, note 1, where La Forest J. said simply: "The situation of the workers and dependents here is in no way analogous to those listed in s. 15(1)"; Canada v. A.U.P.E., (1990) 91 C.L.L.C. 14,001 (Alta. Q.B.): "The distinction between employment in the public sector and employment in the private sector is in no way analogous to the enumerated grounds."

8. (1990), 9 W.C.B. (2d) 293 (B.C. Co. Ct.). The passage quoted is drawn from Canadian Charter of Rights Annotated, case \#15(1): 610080 . 
of the provincial Psychological Association was found not to infringe the equality rights of non-members because, inter alia:

(N)on-registration is not a ground of discrimination analogous to those enumerated in s. 15 of the Charter. The enumerated grounds are those over which an individual has no control, such as race, colour and sex.

A statute restricting the right of persons with criminal records running for election to municipal office was found not to offend s. 15(1) in R. v. McKitka ${ }^{9}$ because:

Distinctions on the basis of criminal record do not come within s. 15(1). While the categories of discrimination enumerated in the subsection reflect personal characteristics over which there is no control, the acquisition of a criminal record is a matter of choice.

These decisions are, it is submitted, simply mistaken. Not all the grounds listed in s. 15(1) of the Charter are beyond the control of those to whom they apply. One's religion can be a matter of choice. And the Supreme Court of Canada extended the protection of s. $15(1)$ in Andrews ${ }^{10}$ to the unlisted ground of citizenship, also a matter at least partially within a person's control. The Ontario High Court of Justice denied that control is a factor in the Leroux case, " discussed in the next section.

\section{PERSONAL CHARACTERISTICS}

The test that seems most popular with the courts at the moment is that which restricts "analogous" grounds of discrimination under s. 15 to those which involve invidious distinctions based on personal characteristics of the individual in question. The test has its most authoritative origins in a passage from the reasons for judgment of McIntyre $\mathrm{J}$. in the Andrews case: ${ }^{12}$

Distinctions based on personal characteristics attributed to an individual solely on the basis of association with a group will rarely escape the charge of discrimination, while those based on an individual's merits and capacities will rarely be so classed.

Since Andrews, "personhood" has been widely regarded as the key to the puzzle of analogousness. To be analogous to the grounds of discrimination listed in s. 15(1) discrimination must, by this view, be based on some characteristic or characteristics of the victim which play a part in defining his or her sense of personhood.

9. B.C. Prov. Ct., Nov. 5, 1986; Canadian Charter of Rights Annotated, case \#15(1): 680020. The court did offer an alternative ground: that the distinction was "not so unfair or unreasonable as to be discriminatory."

10. Supra, note 1.

11. Supra, note 13.

12. Supra, note 1 at 308 . The passage quoted was inspired by similar remarks by Hugessen J.A. in Smith. Kline \& French Laboratories Ltd. v. A.G. Canada (1986), 34 D.L.R. (4th) 584 at 591-92 (F.C.C.). 
The impact of the courts' heavy reliance on the personal characteristics test has generally been to reduce the ambit of a s. 15(1) protection quite sharply. Unlisted forms of discrimination have occasionally been found to involve personal characteristics, and thus to be prohibited by s. 15(1). This was the case, for example, in Leroux v. Cooperators General Insurance $\mathrm{Co}^{13}$ in which Armour J., of the Ontario High Court of Justice held that discrimination between legal and common-law spouses in automobile insurance legislation would violate the Charter on personal grounds; and in Milne v. A.G. Alberta ${ }^{14}$ in which Mason J. of the Alberta Court of Queen's Bench held that a statutory provision terminating the child maintenance responsibilities of a natural father upon marriage of the custodial mother constituted discrimination against the child on the basis of the analogous personal ground of having been born out of wedlock.

For the most part, however, application of the "personal characteristics" test has resulted in the denial of equality claims. A good illustration is Ontario Nursing Home Association v. $R .{ }^{15}$ The challenge was to government funding arrangements under which, in the words of the court, "nursing homes receive less public funding per extended care resident than do homes for the aged and particularly less than municipal homes for the aged."16 In denying that this situation violated s. 15(1) of the Charter with respect to a particular resident of a nursing home, Holland J. of the Ontario High Court of Justice stated:

Any discrimination in this case is based on the type of residence occupied by Mr. Symons - that is a nursing home rather than a home for the aged. It is not based on any of the enumerated grounds in s. 15(1). Can it be said it is based on an analogous ground? Analogous in this context means some personal characteristic ...

The place of residence was chosen by Mrs. Symons for her husband. In the circumstances of this case, the place of residence is not a personal characteristic. ${ }^{17}$

Another is Tanquay v. Ministere de la Main-d'Oeuvre et de la Securite du Revenue, ${ }^{18}$ in which the Quebec Superior Court rejected a claim that s. 15(1) of the Charter was contravened by a provision of social security legislation requiring the repayment of social assistance allowances in certain circumstances which the plaintiff contended were unjustifiable. In so holding, Mackay J. stated that the impugned provision:

... does not provide for any distinction between the persons affected by the section on the grounds of any individual personal characteristics. It covers any and all persons who are or may become recipients of (Man. Q.B.).

14. Alta. Q.B. \#8801-17352, June 8, 1990, unreported.

15. (1990), 72 D.L.R. (4th) 166 (Ont. H.C.).

16. Ibid. at 178.

17. Ibid. at 178-9. Although the question is not relevant to the present discussion, one wonders why the differential treatment of nursing home residents was not considered to involve the factor of physical disability, which is listed in s. 15(1) of the Charter. 
social welfare. It distinguishes but does not discriminate on the basis of an impartial economic criterion: the financial resources of the individual or family needing welfare.

A third representative ruling is Ontario Public Service Employees' Union v. National Citizens' Coalition Inc., ${ }^{19}$ a decision of the Ontario Court of Appeal rejecting a claim that (in the words of the statement of claim) "[t]he appellants' equality rights under s. 15 of the Charter are infringed because taxpayers with business income can deduct contributions to N.C.C. [National Citizens' Coalition] but taxpayers with employment income cannot deduct contributions to organizations advocating views which they support." ${ }^{\text {"20 }}$ Blair J.A. held, for a unanimous court, that:

In my opinion, Canadian taxpayers earning income from employment, who constitute the great majority of the working population, do not constitute a group suffering discrimination on grounds analogous to those enumerated in s. 15(1) of the Charter. This huge group of taxpayers is ... "not linked by any personal characteristics relating to them as individuals or members of a group." They are ... "a disparate and heterogeneous group," linked together only by the fact that they are taxed on their employment income. They are incapable of being discriminated against on grounds analogous to those enumerated in s. $15(1)^{21}$

Other s. 15(1) challenges that have failed after an application of the "personal characteristics" test targeted legislation which, among other things:

- $\quad$ prohibited dental and medical practitioners from incorporating their practices; ${ }^{22}$

- made it an offence for non-lawyers to practice law ("The condition of not being a member of the [Law] Society [of Upper Canada] is not a personal characteristic of the type to which s. 15 relates..."); ${ }^{23}$

- failed to provide casually-employed carpenters the unemployment benefits they would receive if regularly employed; ${ }^{24}$ and

- $\quad$ prevented municipal employees for running for elected civic office. ${ }^{25}$

I believe that although some of these decisions may be justifiable on their merits, the "personal characteristic" criterion of analogousness has contributed nothing useful to them, and will be a hindrance to the solution of future equality problems. An indication of the test's inadequacy can be seen in the inconsistency of certain of the rulings just described. Why is it a "personal" characteristic that one's parents happened not to be married at the time of one's birth (Milne); but not a "personal" characteristic that one's personal care needs require residence in a nursing home (Ontario Nursing Home case)? Why is the marital status of a co-habiting couple (Leroux) more "personal" than the fact that they may require social assistance (Tanguay)?

19. (1990), 69 D.L.R. (4th) 550.

20. Ibid. at 553 .

21. Ibid. at 555 .

22. Re Lister and A.G. Ontario (1990), 67 D.L.R. (4th) 732 (Ont. H.C.).

23. Sussman v. Law Society of Upper Canada (1991), 20 C.R.D. 525.20-02 (Ont. S.C., June 15, 1990).

24. A.G. Canada v. George (1990), 19 C.R.D. 400.50-01 (F.C.A., Oct. 29, 1990).

25. Re Rheaume and A.G. Ontario (1989), 70 O.R. (2d) 602 (Ont. H.C.). 
Doubt about the efficacy of the "personal characteristics" test thickens when one takes account of the fact that although certain factors are more commonly important to one's sense of "personhood" than others, the range of factors that are significant in this regard is very broad, and varies widely from person to person. For some people, race, or religion, or ethnic background, or age, are vital components of their sense of themselves. For others (even for the same persons in different circumstances) these factors are of minor significance compared to such matters as poverty, profession, or area of residence. The truth is that an almost inexhaustible list of factors are "personal" characteristics; but that how personal they are depends on the attitude, from time to time and situation to situation, of the individuals involved.

Perhaps the most serious difficulty with the "personal characteristic" standard is that it is inherently incompatible with the notion of "discrimination," of which it is supposed to be an indicator. What are some of the most indisputably "personal" traits of all? A short list would undoubtedly include fingerprints, DNA profiles, individual abilities, and personality. Yet distinctions based on any of those factors would not be considered discriminatory. Decision-making on the basis of such individualized characteristics is the antithesis of discrimination. Consider again the general explanation of discrimination that Mr. Justice McIntyre articulated on behalf of this Supreme Court of Canada colleagues in the Andrews case: ${ }^{26}$

Distinctions based on personal characteristics attributed to an individual solely on the basis of association with a group will rarely escape the charge of discrimination, while those based on an individual's merits and capacities will rarely be so classed.

Discrimination involves a reliance on stereotypes ("Women are weak"; "Men are insensitive"; "Certain races are shiftless"), rather than on personal merit or demerit. To employ the "personalness" of distinguishing factors as a measure of discrimination is therefore an inherently contradictory exercise.

When a series of judicial decisions yields results that seem pragmatically sound for the most part, but are difficult or impossible to understand in terms of the theoretical standard upon which they purport to have been based, there is reason to speculate that the professed standard is not the real basis for the decisions. I believe that is the case here. If the decisions already discussed leave any doubt on that score, it has been removed by a recent ruling of the Supreme Court of Canada on the subject of "personal characteristics."

In $R$. v. $S .^{27}$ the court was asked to hold that the uneven application across Canada of a program of alternative sentencing measures under the Young Offenders Act violated s. 15(1) of the Charter. The court declined to do so. The reasons for judgment of Chief 
Justice Dickson, on behalf of a unanimous panel, applied the "personalness" criterion in an interesting way: ${ }^{28}$

I find the substantive distinction to be geographic and based upon the province of residence of young offenders. ... [T] he absence of this benefit in the province of Ontario must be considered to be a legal disadvantage imposed upon young offenders resident in that province. ...

$\cdots$

In the context of a distinction based upon province of residence, the inquiry turns to whether the distinction is based upon a personal characteristic. ...

Obviously the federal system of government itself demands that the values underlying s. 15(1) cannot be given unlimited scope. The division of powers not only permits differential treatment based upon province of residence, it mandates and encourages geographical distinction. There can be no question, then, that unequal treatment which stems solely from the exercise, by provincial legislators, of their legitimate jurisdictional powers cannot be the subject of a s. 15(1) challenge on the basis only that it creates distinctions based upon province of residence. ... To find otherwise would be to completely undermine the value of diversity which is at the foundation of the division of powers.

However, the matter does not end there. This appeal raises the issue of the impact of $s .15(1)$ on distinctions based upon province of residence in the application of a valid federal law. Thus, the question is whether in that circumstance province of residence can be considered a "personal characteristic." ...

It is necessary to bear in mind that differential application of federal law can be a legitimate means of forwarding the values of a federal system. ... A brief review of Canadian constitutional history clearly demonstrates that diversity in the criminal law, in terms of provincial application, has been recognized consistently as a means of furthering the values of federalism. Differential application arises from a recognition that different approaches to the administration of the criminal law are appropriate in different territorially-based communities. ...

In my opinion, the question of how young people found to have committed criminal offences should be dealt with is one upon which it is legitimate for Parliament to allow for province-based distinctions as a reflection of distinct and rationally based political values and sensitivities. ... Differential application of the law through federal-provincial co-operation is a legitimate means whereby governments can

Ibid. at 104-8 (emphasis in original). Among the elisions from the material quoted is a passage (at 106) in which Dickson C.J.C. referred to an earlier decision, R. v. Turpin (1989), 39 C.R.R. 306, in which the Supreme Court of Canada refused to strike down another federal criminal statutory provision that did not apply to every province. Several things are of interest about Turpin and this reference to it. For one thing, Wilson J., who wrote for a unanimous Court in that case, pointed out, and Dickson C.J.C. saw fit to italicize the passage when quoting it in $S$., that she was not denying the possibility that province of residence could be a prohibited ground of discrimination in other circumstances. Second, although he said he agreed with Wilson J. that such determinations are appropriately made on a case-by-case basis, he characterized his own approach to the problem as "principled" (at 107). Finally, he referred to the Wilson decision in Turpin, which turned on the "discrete and insular minority" factor to be discussed below, as having held that the geographic distinction in that case was "not based upon a personal characteristic" (at 106). 
overcome the rigidity of the "watertight compartments" of the distribution of powers with respect to matters that are not easily categorized or dealt with by one level of government alone. Consequently, I find that in this case the legislation does not amount to a distinction which is based upon a "personal characteristic" for the purposes of s. 15(1) of the Charter.

Few would take issue with the principle which animates these passages - that in applying Charter rights account must be taken of other constitutional imperatives such as the federal nature of Canada - even if not everyone would agree with the manner in which the principle was applied in this case. What is perplexing is Chief Justice Dickson's attempt to link his reasoning to the notion of "personal characteristics." How can one's province of residence be a more or less "personal" characteristic, depending upon the utility of the particular uses of that distinction in serving the values of federalism? Surely the label "personal" is being used here, as in many of the cases described earlier, to mask some other factor.

The inarticulate factor, in my opinion, is relevance. In the Andrews case both McIntyre J., whose general observations were adopted by the majority, and La Forest J., who wrote separate concurring reasons, employed the term "irrelevant personal differences." ${ }^{29}$ It is unfortunate that the adjective "irrelevant" was omitted from Justice McIntyre's more frequently cited explanation of "discrimination," quoted earlier. By "irrelevant" the court seems to have meant those differences which cannot be reasonably justified in the particular context. A distinction between persons of native ancestry and others would rarely be a relevant factor in the employment of federal government employees (apart from affirmative action programs) for example, but it would perhaps be relevant to the employment of counsellors for other persons of native ancestry.

The province in which one resides is, in my opinion, a "personal characteristic," though admittedly one which varies widely in importance among individuals. (Having recently moved from one province to another, I am conscious of the frequency with which I am described as a "Manitoban," or an "Albertan," and also of the frequency with which I am asked whether I have yet re-adjusted my regional affiliations.) But the question of whether a particular distinction based on province of residence constitutes "discrimination" under the Charter is unrelated to "personalness"; it depends upon whether such a distinction is relevant, in the particular circumstances, to proper decision-making factors. In the $S$. case, Chief Justice Dickson and his colleagues considered province of residence to be relevant, given the federal nature of the country, to decisions about implementing alternative sentencing measures for young offenders, and so there was no discrimination "in this case," to use the words of the Chief Justice. Various of the other "analogous grounds" cases mentioned above can also be explained much more plausibly on the basis of "relevance" than of "personalness."

Questions of relevance and justification could be dealt with under s. 1 of the Charter as "reasonable limits in a free and democratic society," of course. The difficulty with leaving all such decisions to be made in that context is that "reasonable limits" are 
required to be "prescribed by law," and the onus of demonstrating their justifiability always lies with the governmental authorities. To legitimate the thousands of relatively minor common-sense distinctions that sound governmental judgment requires to be made every day, a less cumbersome device is required. Early decisions under s. 15(1) of the Charter employed the "similarly situated" standard for this purpose: distinctions on prohibited grounds would not be considered discriminatory unless the circumstances being compared were "similarly situated." To revert to an earlier hypothetical illustration, if persons employed as counsellors for native Canadians were not considered to be situated similarly to other employees of the Government of Canada, a distinction on that basis would be justifiable. The Supreme Court of Canada has eschewed the "similarly situated" formula, however, holding in the Andrews case that it is an unsatisfactory standard. The notion of "irrelevant personal differences" is capable of serving the same purpose though, and it appears that it is being so employed, at least sub rosa. The problem is that by usually omitting the crucial adjective "irrelevant" from their discussions, and emphasizing the word "personal," the courts have created a fertile source of confusion. The confusion is compounded by the fact, to be discussed more fully below, that questions of relevance or justifiability are logically distinct from the matter of discriminatory grounds.

Not every court has fallen victim to this confusion. A few judges have managed to keep the issue of "analogous grounds" sharply distinct from that of relevance or justification. The analysis of Coultas J., of the British Columbia Supreme Court, in Brown v. Minister of Health, ${ }^{30}$ for example, is a model of lucidity. The issue in that case was whether the British Columbia government had discriminated against AIDS patients, the majority of whom were homosexuals, by refusing to provide funding to offset the high cost of the drug AZT. Evidence indicated that British Columbia was the only Canadian province that denied such funding, and that it did fund expensive drugs for the treatment of cancer and organ transplants. Coultas J. had no hesitation finding that "discrimination based on sexual orientation contravenes the equality provisions of the Charter." ${ }^{31}$ Nevertheless, he held, discrimination had not occurred. After rejecting arguments that the evidence indicated direct, intentional discrimination, he also denied the existence of indirect "adverse impact" discrimination due to the differential treatment of AIDS patients and cancer and transplant patients, remarking that: ${ }^{32}$

In my view, the distinction between HIV [AIDS] drug therapy and cancer and transplant drug therapy is an accommodation of the medical difference.

While I do not find Mr. Justice Coultas' findings of non-discrimination to be persuasive on the facts, I submit that his clear differentiation between the "grounds" issue and the "relevance" or "justification" issue is far preferable to the melding of issues that occurred in $S$. and other "personal characteristics" decisions.

Ibid. at 459. Counsel for the Crown had conceded that such discrimination "is akin to the enumerated grounds," at 458.

Ibid. at 463. 
The way had been pointed for that approach by the British Columbia Court of Appeal the previous year, when, in Skalbania v. Wedgewood Village Estates Ltd. ${ }^{33}$ it declined to strike down certain nepotism provisions of the Bankruptcy Act, holding that although distinctions based on family relationship "might be found sufficiently analogous to the enumerated grounds of discrimination to constitute a breach of this subsection," the provisions in question were not discriminatory:

In defining the classes of persons whose dealings are subject to review, there are sound reasons for drawing a distinction between related persons and others.

It would not be entirely accurate to assert that "personalness" by itself can never play a useful role in the determination of analogous grounds under s. 15(1) of the Charter. It does serve to rule out certain possible grounds of distinction which, while not rationally relevant to sound decision-making, are nevertheless beyond the scope of "discrimination," as that concept is commonly understood. Suppose a decision were based on the toss of a coin, or the propitious conjunction of certain planets (or of the hands of the clock, as was reputedly the case with former Prime Minister Mackenzie King). Although irrational, such decisions would not be considered discriminatory in the orthodox sense, since they would not involve stereotypes based on the personal characteristics of those affected. The "personalness" test would screen out such cases. But how often would they arise? Perhaps, when they did, it would not be such a bad thing if they were outlawed, anyway. Do we really want our governmental decision-makers employing the occult methods of Mackenzie King?

In sum, it is difficult to find anything good to say about the "personal characteristics" test of analogousness, other than that it masks a useful notion - social relevance - that would be more useful if unmasked. Although the writer expressed mild approval for the "personalness" criterion in earlier writing on $\mathrm{s}$. 15, I am convinced, now that I see how the case law has developed, that this approval was ill-advised.

\section{PRIOR GROUP DISADVANTAGE}

Numerous "analogous grounds" decisions, including many of those which have made reference to "personal characteristics," have employed the "discrete and insular minorities" approach. The grotesque expression "discrete and insular minorities," coined quite casually by Stone J., of the United States Supreme Court, in a footnote to his 1938 reasons for judgment in United States v. Carolene Products $\mathrm{Co}^{34}{ }^{34}$ has become a label for the notion that the greatest benefit of the rather limited equality rights protected by the U.S. Constitution should accrue to the members of certain disadvantaged groups. ${ }^{35}$ Rights Annotated, \#15(1): 520160.

34. (1938), 304 U.S. 144 at 152-53, note 4.

35. See Ely, supra, note 4. 
The term was borrowed by Justices McIntyre and Wilson in the Andrews case, ${ }^{36}$ the Supreme Court of Canada's first Charter equality case, and as it happened, its first analogous grounds case as well. That case established that discrimination on the basis of citizenship falls within the Charter's protection. While the references to "discrete and insular minorities" in that decision were not crucial to the ruling, the phrase was later used, conclusively, in the court's second analogous grounds case: $R$. v. Turpin. ${ }^{37}$ The question in Turpin was whether a Criminal Code provision which entitled certain accused persons to trial by judge alone in Alberta, but not in other provinces, violated the Charter's s. 15(1) guarantees of security "before and under the law," and of "equal protection and equal benefit of the law without discrimination." The court held, unanimously, that it did not. Madame Justice Wilson, who wrote for the court, articulated, as the basis of her decision, a restrictive view of the scope of s. 15(1). Implicit in the concept of "discrimination," she held, is the principle that the benefit of s. 15(1) is available ("in most but perhaps not all cases") only to members of "discrete and insular minorities" which suffer disadvantage over and above the immediate cause for complaint: $^{38}$

A finding that there is discrimination will, I think, in most but perhaps not all cases, necessarily entail a search for disadvantage that exists apart from and independent of the particular legal distinction being challenged.

While stressing that she was not ruling out the possibility that province of residence or of trial could ever be "a personal characteristic of the individual or group capable of constituting a ground of discrimination," she held that "it is not so here. ${ }^{139}$

[I]t would be stretching the imagination to characterize persons accused of one of the crimes listed in $\mathbf{s}$. 427 of the Criminal Code in all the provinces except Alberta as members of a "discrete and insular minority."

It is not surprising that since Turpin, other courts have frequently applied the "discrete and insular" test when faced with the task of identifying analogous grounds under s. 15(1) of the Charter. The test has been used, for example, to support holdings that:

- Provincial education legislation rendering employees of school boards ineligible to run for election as board members does not offend s. 15(1), even though certain other public sector employees in the province have greater rights in this regard, since: "School teachers are a heterogeneous group linked together only by their profession or occupation, and are, therefore, not a discrete and insular minority sharing a common personal characteristic." 40

- Federal election legislation making it easier for unlisted voters in rural areas than unlisted voters in urban areas to be added to voting lists does not discriminate

Supra, note 1.

Supra, note 28.

Ibid. at 336.

lbid.

Sacco v. A.G. Ontario (Ont. H.C.J., Feb. 8, 1991, unreported). Description and quoted passage taken from Canadian Charter of Rights Annotated, \#15(1): 640070. 
within the meaning of s. 15(1) because urban voters are not members of a discrete and insular minority. ${ }^{41}$

- A statutory provision denying the right of jury trial in actions against municipalities, but not in actions against other defendants, does not infringe the Charter equality rights of other defendants because they are not part of a group that can be characterized as a discrete and insular minority. ${ }^{42}$

- Discrimination against homosexual prisoners of a federal penal institution in regard to the privilege of conjugal visits does contravene s. 15(1), because homosexuals are, among other things, members of a discrete and insular minority. ${ }^{43}$

The courts have not been entirely consistent in restricting analogous forms of discrimination to those which affect discrete and insular minorities. In Schachter v. $R .{ }^{44}$ for example, legislation which treated adoptive parents more favourably than natural parents was held to violate s. 15(1). Since natural parents are hardly a disadvantaged group, this is difficult to reconcile with the test.

Occasionally, too, the "discrete and insular" test has been applied questionably. In $R$. v. Duvivier, ${ }^{45}$ for example, the common-law wife of an accused man was refused spousal immunity from testifying against the accused, despite her allegation that treating her different than a legal spouse violated her equality rights. Farley J., of the Ontario Supreme Court, dealt with the equality issue in part as follows:

The witness has been discriminated against based upon her marital status. She has been treated differently than she would have had she been married to the accused. However, has she been discriminated against as to her status of someone being in a quasi-marital relationship? To what group does the witness truly belong? While she may be a member of the group of persons involved in a quasimarital relationship, is this the appropriate group in which to place her? If it is not, it would have the same effect as if she were a member of a group of those persons who have red hair and blue eyes. In the context of the subject analysis, she belongs to a much larger group. The witness is not a spouse. However, it is not just members of a quasi-marital relationship who are compellable. A daughter is compellable against her mother, a father against his son - all no matter whether they live in the same household or not. The true group of which the witness is a member in this context are all those persons who are non-spouses and are therefore compellable to testify. In that regard the witness is not a member of a "discrete and insular minority" ...

The conclusion that common law wives are not members of a group that has historically suffered all the prejudice and disadvantage that characterizes acknowledged "discrete and

Scott v. Chief Electoral Officer (1990), 71 D.L.R. (4th) 516 (B.C.S.C.). Guldborg v. Lautenbach (1990), 70 D.L.R. (4th) 747 (Ont. H.C.).

Vesey v. Commissioner, Correctional Service (1989), F.C.J. 1003 (F.C.T.D.). The view that s. 15(1) prohibits discriminations against homosexuals was also expressed in Brown v. Minister of Health. supra, note 30, though the Charter challenge was dismissed on other grounds.

(1990), 66 D.L.R. (4th) 635 (F.C.A.). The decision could be explained in terms of the test only if the group discriminated against were considered to be the children, rather than the parents. (1990) 19 C.R.D. 725.330-02 (Ont. S.C., Sept. 26, 1990). 
insular minorities" such as unpopular races, the mentally handicapped, and homosexuals suggests a serious misunderstanding of the concept.

For the most part however, courts do not appear to have experienced much difficulty applying the "discrete and insular minorities" standard. I have been an immoderate critic of the standard, ${ }^{46}$ but not, generally, because it has been misunderstood or hard to employ. My chief criticism has been that the test has shrunk the ambit of the equality guarantee much more severely than either the language of s. 15(1) or the common understanding of Canadians fairly permits. Having said my piece on that issue elsewhere I will say no more here. I have suggested in earlier commentaries that the Supreme Court of Canada has left itself room to retreat from the concept, but I have to acknowledge that the current case law still reflects wide acceptance and application of the test.

A secondary complaint I have about the test is that the words in which it is couched - the expression "discrete and insular minorities" - is a linguistic abomination. "Minorities" would exclude women, who are on everyone's list of deserving beneficiaries of s. 15(1), and "insular" smacks of ghettos, institutions, and "separate but equal" facilities, phenomena that typified majority treatment of the disadvantaged in the 1930s, when Mr. Justice Stone wrote his footnote, but not the accepted attitudes of the integrating 1990s. It is for the latter reason that this section of the article is headed "Prior Group Disadvantage," which I think expresses much more accurately the idea that Wilson J. and others were trying to label when they plundered the Stone footnote.

It is interesting to note that the bulk of the judicial decisions (all of those cited above, in fact) in which this test, however labelled, has been used to decide whether distinctive treatment amounts to discrimination on analogous grounds would probably have reached the same conclusion on the merits by simply asking whether the distinction was "relevant" in the sense discussed in relation to "personal characteristics." In other words, the courts' cardinal concern has again been to decide whether the distinction in question is socially justifiable.

This is not to say that the prior group disadvantage restriction is without significance to the application of unlisted grounds of discrimination. Discrimination on the basis of language offers a good illustration. As I will explain later, I believe language discrimination to be a type of discrimination analogous to those listed in s. 15(1). But if the courts continue to require prior group disadvantage as a condition precedent to equality entitlement, only unfavourable treatment of the languages of disadvantaged groups (native Canadians and many, though not all, immigrants, for example) will qualify as discrimination. That raises interesting regional questions, by the way. Would English, but not French, qualify for protection in Quebec? French, but not English, in Manitoba? What about language restrictions against English by a predominantly French-speaking town or village in Manitoba? In this area, as in so many others, application of the "prior

46. See D. Gibson, "Equality For Some" (1991) N.B.L.R. (forthcoming); "Constitutional Fathers-In-Law: Judicial Amendment of the Canadian Constitution," Proceedings of Duke University Supreme Courts Conference, 1991 (forthcoming). 
group disadvantage" qualifier to equality rights is likely to generate legal fees in perpetuity.

\section{STABILITY}

Justice La Forest referred in Andrews to other possible common characteristics of the grounds listed in s. 15(1). One of these was "immutability":47

The characteristic of citizenship is one typically not within the control of the individual and, in this sense, is immutable. Citizenship is, at least temporarily, a characteristic of personhood not alterable by conscious action and in some cases not alterable except on the basis of unacceptable costs.

"Immutable" means unchangeable. Most forms of discrimination expressly listed in section 15 are unchangeable: race, national or ethnic origin, colour, sex (if one ignores the changes possible through surgery and hormone treatments), and some types of mental or physical disability. Age is a characteristic that changes constantly, of course, but even it can be considered "immutable" in that it is "not within the control of individuals"; there is nothing one can do to alter one's age at any moment in time. Religion is not an immutable characteristic, however. People can change their religious affiliations at will. Not all disabilities are immutable, either; some are curable, others are at least ameliorable. It cannot be considered, therefore, that the lowest common denominator of the grounds listed in section 15 is "immutability" in the usual sense of the word.

But Justice La Forest was clearly using the word in a special way. He described citizenship as immutable "in this sense," acknowledging that it can be a temporary characteristic. He found it to be an immutable condition in part because it is not "alterable by conscious action." By "conscious action" he must have meant the unilateral action of the citizen in question, since most changes of citizenship are initiated by the individual's conscious action. His second reason for labelling citizenship immutable was that it can sometimes be changed only by incurring "unacceptable costs," which was doubtless intended to refer to more than economic costs.

In this special sense, even religion might be considered "immutable." Changes of religion usually require more than just the individual's "conscious action"; in most cases there must also be an acceptance of the convert by authorities of the new faith. The changes of inner conviction that often accompany such conversions may also be considered beyond the individual's conscious control. There may be "unacceptable costs" involved in religious conversion for some people, too: painful struggles with conscience, family ruptures, social ostracism, and so on. Disabilities that are ultimately curable might also be considered "immutable" while they last.

In the same special sense, many other characteristics that are not expressly mentioned in section 15(1), but upon which discrimination is often based, could be considered 
"immutable": political affiliation, marital or family status, social rank, and perhaps even membership in trade unions or other occupational and social organizations of cardinal significance to the individual's life. Apart from the aspect of organizational endorsement (which is unlikely to be considered essential, since it does not typify the characteristics listed in section 15) the same would be true of factors such as language, sexual orientation, and economic status. In Brooks v. Canada Safeway Limited ${ }^{48}$ Chief Justice Dickson, writing for the Supreme Court of Canada, seemed to approve the view that pregnancy is an "immutable characteristic, or incident of gender."

"Immutability" may thus be considered a plausible test for characteristics "analogous" to those specified in section 15 , but only if the term is interpreted to mean something like: "not immediately changeable except with great difficulty or cost," and the application of the concept is nourished by an understanding of the realities of everyday life. Since the equality involved has to do with relative, not absolute, permanence, it is, in the writer's view, more accurately labelled "stability" than "immutability."

Is stability a helpful test? Would the courts be materially assisted in identifying "analogous" grounds of discrimination if Justice La Forest's thoughts about "immutability" were adopted? The test would certainly permit them to rule out distinctions based on easily alterable characteristics like style of dress, hair length, or the use of facial make-up. But what about more important or more deeply ingrained characteristics? The significance of the stability test may be usefully examined in relation to a factor like place of residence, which is central to the issue of geographic discrimination.

Early litigation under section 15(1) included numerous assaults on laws that treated persons in certain parts of Canada less favourably than persons in similar situations elsewhere in the country. Several of those challenges were successful. ${ }^{49}$ The fear has sometimes been expressed that a stability test would overrule those decisions. Would that be so? Is the fact that a person resides in a particular part of the country an "immutable" characteristic in the special sense in which the term was employed by Mr. Justice La Forest? There are no formal barriers to prevent anyone from changing his or her residence within Canada at will. Yet if we examine the question realistically we find, especially within the groups whose members most frequently experience discrimination, compelling influences to remain where they are: family and marital ties, cultural bonds, the cost of relocation, employment pressures. It would be highly fictitious to tell a native trapper from the Northwest Territories, or the spouse of a Nova Scotia fisherman, or a francophone shop clerk from Trois Rivières, that they are free to move anywhere in Canada. Because of the powerful deterrents to migration that so frequently exist in the real world, a person's place of residence is for many an "immutable" characteristic in the sense that Justice La Forest appears to have used the expression in Andrews. In many cases it is little less so than citizenship.

48. [1989] 4 W.W.R. 193 at 212 (S.C.C.). The words quoted came from a factum filed in the case, but appear to have been quoted with approval. Discrimination against pregnant women was found in that case to be "based on sex, or, at least, strongly 'sex related" (at 213).

49. R. v. Punch, [1986] 1 W.W.R. 592 (N.W.T.S.C.); R. v. Bailey (1985), 17 C.R.R. 1 (Y.T.S.C.); R. v. Emile, [1988] N.W.T.R. 196 (C.A.). 
The Supreme Court of Canada has told us in Turpin and again in $S$. that certain distinctions based on province of residence do not offend s. 15(1) (in the one case because the claimant group did not constitute a "discrete and insular minority," and in the other because the tolerance for diversity implicit in federalism justified the distinction). But the court did not deny that geographic discrimination might be prohibited by the Charter in an appropriate case. Madam Justice Wilson remarked in Turpin that: ${ }^{50}$

I would not wish to suggest that a person's province of residence or place of trial could not in some circumstances be a personal characteristic of the individual or group capable of constituting a ground of discrimination. I simply say that it is not so here.

It appears, therefore, that the determination of analogousness is situation-specific. If the factor of stability is to play a role in the process, it is therefore likely to be applied in a particularized manner, with courts examining, in the case of alleged geographic discrimination, the relative stability of individual claimants' geographic rootedness. A similar individualized approach might be taken to the stability of other possibly analogous grounds of discrimination, such as poverty, political affiliation, or family status.

But trying to determine the precise degree of relative permanence that ought to be judged "stable" in an ever-changing world would be an extremely difficult and always controversial task. Moreover, decisions as to whether distinctions based on particular conditions of poverty, or place of residence, or whatever, are acceptable can usually be dealt with more easily under the rubric of "relevance" than of "stability." One should also bear in mind that all distinctions, whether based upon listed or unlisted grounds, must be substantial to constitute discrimination..$^{51}$ It is highly questionable, therefore, whether the stability factor will add very much to equality analysis in the long run.

\section{OTHER CONSTITUTIONAL PROTECTION}

Section 15 of the Charter cannot be read in a vacuum; it is part of a larger Constitution, and its interpretation is inevitably influenced by other features of that Constitution. We have already seen how, in $R$. v. S., ${ }^{32}$ Chief Justice Dickson took account of the federal nature of the Canadian Constitution to justify interprovincial discrepancies in the application of federal criminal law. To a certain extent, therefore the extension of s. 15(1) protection to some new analogous ground of discrimination might be hampered or otherwise influenced by the existence of other constitutional imperatives that either inhibit or encourage the extension in question.

Linguistic discrimination provides a case (or perhaps several cases) in point. The Charter entrenches, in sections 16 to 23, certain specific rights relating to the use of the

so. Supra, note 28 at 337.

51. See Gibson, supra, note 1 at 116-17.

52. Note 27 above. The Supreme Court of Canada has not been entirely consistent in this regard, however. In Mahé v. Alberta (1990), 68 D.L.R. (4th) 69 at 87, for example, it held that neither s. 15 nor $\mathrm{s} .27$ of the Charter could be employed to help interpret minority language education rights guaranteed by s. 23 of the Charter. 
English and French languages in New Brunswick and at the federal level. (Section 133 of the Constitution Act, 1867 contains additional language guarantees applicable to the provinces of Quebec and Manitoba.) The inequalities implicit in this constitutionallymandated differentiation between federal and provincial orders of government, and between some provinces and others, cannot be attacked by means of s. 15(1), since that provision has no greater constitutional authority than sections 16 to 23. In McDonnell v. Federation des Franco-Columbiens ${ }^{53}$ the British Columbia Court of Appeal dismissed a claim that the requirement that English be used in all documents filed in British Columbia courts violated s. 15 . While there could be no doubt that the requirement amounted to at least prima facie discrimination on the basis of language, the court held that it was not a breach of s. 15, because sections 16 and 19, which bestow an explicit right to use either English or French in courts and other governmental institutions in New Brunswick and at the federal level, implicitly deny that right in the courts and institutions of provinces other than New Brunswick. Craig J.A., who wrote for the court, adopted the Crown's contention, based on the expressio unius principle of interpretation, that ${ }^{54}$

[sections] 16 to 22 are exhaustive of the subject of language rights, that there is nothing in any of these sections which would affect the power of British Columbia to pass Rule 42 [the English-only requirement] and that, therefore, the Federation cannot rely on s. 15."

In support of this conclusion Craig J.A. cited passages from the majority reasons for judgment of Beetz J. in the Supreme Court of Canada's rulings of MacDonald v. Montreal (City of $)^{55}$ and Société des Acadiens du Nouveau-Brunswick v. Association of Parents for Fairness in Education ${ }^{56}$ to the effect that language rights under the Charter ought to be interpreted more strictly and applied more narrowly than other rights.

This should not be read as a rejection of minority language as an analogous ground of prohibited discrimination, however. Apart from the difficulties discussed earlier concerning the regional implications of the "prior group disadvantage" test as applied to language, linguistic discrimination would appear to meet all the suggested criteria of analogousness, and therefore to be proscribed by s. 15(1) in all respects other than those

(1986), 31 D.L.R. (4th) 296.

Ibid. at 299. A possibly different approach was taken by the Saskatchewan Court of Appeal in Reference Re French In Criminal Proceedings (1987), 44 D.L.R. (4th) 16 at 37:

Nor, in our view, does the presence in the Charter of the language provisions of ss. 16 to 20, or the deletion from an earlier draft of s. 15(1) of the word "language," have the effect necessarily of excluding from the reach of s. 15 the form of distinction at issue in this case.

It would be wrong to make too much of the contrast, however, since the issue in the Reference differential application of federal language provisions to various provinces - was very different than the issue in McDonnell, and the decision was implicitly reversed by the Supreme Court of Canada in Turpin and in S. This was, moreover, a pre-Andrews decision, in which the Saskatchewan Court disapproved of the analogous grounds approach eventually adopted by the Supreme court of Canada in Andrews. 
which may be implicitly authorized by other constitutional provisions. The concluding words of Craig J.A. in the McDonnell case make this clear.: ${ }^{57}$

Section 15 is a guarantee against discrimination, and is a legal right. While discrimination based purely on language may be within s. 15, our concem is whether the concept of "official language" comes within it. Having regard to the provisions of ss. 16 to 22 and the other sections dealing with languages and the judgments of the majority in MacDonald and Société des Acadiens, I do not think that it does.

\section{CONCLUSION: WHY ARE WE DOING ALL THIS ANYWAY?}

The "analogous grounds" decisions reviewed above appear to have addressed, and often to have confused, at least three distinct types of questions:

(a) The social utility of the distinctions being made;

(b) the categories of persons entitled to benefit by the Charter's equality protections; and

(c) the grounds upon which prohibited discrimination is based.

"Analogousness" relates necessarily to only the third issue.

The social utility issue is properly dealt with in one of two ways. It may be treated as a section 1 problem: a question of whether the distinction, if discriminatory, can nevertheless be "demonstrably justified" as a "reasonable limit ... in a free and democratic society." Because s. 1 places the onus on government, requires the distinction to be "prescribed by law," and entails an uncomfortable initial acknowledgement that the government's conduct is "discriminatory," this method of justifying distinctions has not been much employed. The second method avoids those problems, however, by requiring only that the distinction be considered "relevant" in the circumstances: suitable to socially acceptable decision-making in the particular area of governmental activity concerned. If the distinction in question is not based on "irrelevant personal differences" it is not discrimination in the first place, and the inquiry need proceed no further.

In my view, a high percentage of the analogous grounds decisions to date, conspicuously including the Supreme Court of Canada's ruling in $R$. v. S., have really been about the relevance to proper governmental decision-making of the distinction employed, despite their surface references to criteria of analogousness. I have no general quarrel with the merits of the conclusions reached (sometimes they seem correct to me, and sometimes they don't), but I fear that it does a serious disservice to the rational development of equality law under the Charter to confuse the issue of "discrimination" with that of "grounds." If courts would focus openly on the first word of the "irrelevant personal differences" formula, rather than the second, this source of confusion would be eliminated. Since "irrelevance" is a component of "discrimination" of all types, whether based on listed or unlisted grounds, there would be no need to mention the notion of "analogousness" at all. 
The "protected persons" issue, injected into the process by the Supreme Court of Canada's adoption of the "discrete and insular minorities" or "prior group disadvantage" test in Andrews and Turpin, is also a question distinct from the prohibited grounds of discrimination. While it was first promulgated in decisions relating to whether noncitizenship or province of residence are analogous to the factors listed in s. 15(1), the concept of prior group disadvantage was said to underlie all discrimination. It was because the Supreme Court found prior group disadvantage to be inherent in all listed forms of discrimination that it restricted unlisted forms in the same manner. The principle has subsequently been applied by other courts to deny the protection of s. 15(1) to even the victims of harmful distinctions made on the basis of listed grounds if they are not members of groups suffering prior disadvantage. ${ }^{58}$ Although it would be pragmatically tempting, to one who believes that the prior group disadvantage ("discrete and insular minority") restriction was a regrettable judicial amendment of Charter rights, to contend that the restriction should be limited to the "analogous grounds" situations where it arose and not extended to listed grounds, the logic of applying it to all types of discrimination seems irrefutable. The prior disadvantage principle has nothing to tell us, therefore, about analogous grounds, other than that, as in the case of listed grounds, "discrimination" must be present. Thus, the cases in which the "discrete and insular minorities" or "prior group disadvantage" test has been employed can offer no guidance to the meaning of "analogousness" itself.

Only the "grounds" issue truly engages the notion of analogousness. Three of the criteria discussed above - control, personalness, and stability - do relate, if properly applied, to grounds of discrimination. Control, however, is an unacceptable factor for the reasons discussed above. Personalness may be a valid factor, but, as we have seen, it is rarely encountered in cases where "relevance" is not the real issue. Only in "toss of the coin"or astrological types of situations does the "personalness" of discriminatory decisionmaking become germane, and those situations are both unusual in the extreme and capable of being dealt with in other ways. The element of stability ("immutable in that sense") does typify the prohibited grounds of discrimination listed in s. 15(1), and does provide a possible way of denying constitutional protection to transitory characteristics like dress and hair-styles. While the prior group disadvantage ("discrete and insular minorities") test continues to be used to define the beneficiaries of s. 15(1), however, distinctions based on such characteristics would not be considered discriminatory in any event.

I conclude, therefore, that the concept of analogousness contributes little or anything, other than confusion, to the application of equality guarantees under s. 15(1) of the Canadian Charter of Rights and Freedoms. If courts openly applied "relevance," or social utility, as the measure of the unacceptable distinctions that constitute discrimination, and continued, if they must, to restrict the protection of $s .15$ to members of groups suffering prior disadvantage, they would eventually realize that they have all the decisional flexibility they require to resolve equality disputes soundly, and that the question of "analogous grounds" is a non-issue. stringent penalties for non-payment of fines by adults than for minors. The decision turned on the fact that adults are not members of a "discrete and insular minority." 